\title{
A AIDS SOB 0 OLHAR DA COMPANHEIRA CONTAMINADA
}

\author{
AIDS UNDER THE CONTAMINED PARTNER'S VIEW \\ EL SIDA BAJO LA MIRADA DE LA COMPAÑERA CONTAMINADA
}

\begin{abstract}
Maria Grasiela Teixeira Barroso ${ }^{1}$ Carla Correia Lima Miranda ${ }^{2}$ Patrícia Neyva da Costa Pinheiro ${ }^{3}$
\end{abstract}

\begin{abstract}
RESUMO: Objetivou-se refletir sobre o problema da contaminaçāo pelo HIV em mulheres que têm relacionamento heterossexual estável. Utilizamos entrevista semiestruturada, enfoque etnográfico, com mulheres atendidas no hospital de doenças infecto-contagiosas, incluindo-se DSTs, no Estado do Ceará. Na entrevista. foram feitas perguntas envolvendo medidas de prevenção na relação do casal, a reação diante da soropositividade para o HIV, o sentimento em relação aos filhos e a convivência entre parentes e amigos. Ao analisarmos as entrevistas identificamos ausência de medidas preventivas, falta de busca sobre informações no que diz respeito ao HIV, revolta das companheiras e sua preocupação com os filhos, bem como a difícil situação entre parentes e amigos.
\end{abstract}

PALAVRAS-CHAVE: Mulher - AIDS - Reação à soropositividade.

ABSTRACT: Our objective was to reflect upon the HIV contamination in women who has a stable relationship. We have used semistructure interview with an ethnographic way of focussing to the women from Infections diseases hospital, also STD's at the State of Ceará. At the interview questions about prevention in the couple relationship, the HIV positive result reaction, the feelings toward children and living with family and friends have been made. The interview analysis has identified the absence of prevention, the lack of search about HIV information, the wives wrath and the worries about the children, and also the difficult situation between family and friends.

KEYWORDS: Woman - AIDS - Positive Result reaction.

RESUMEN: Se objetivo reflexionar sobre el problema de la contaminación por el HIV en mujeres que tienen relacionamiento heterosexual estable. Utilizamos entrevista semi-estructurada, enfoque etnográfico, com mujeres atendidas en el hospital de enfermedades infecto-contagiosas, incluyendose DSTs, en el Estado de Ceará. En la entrevista fueron hechas preguntas envolviendo medidas de prevención en la relación de la pareja, lareacción delante de la positividad del suero para el HIV, el sentimiento en relación a los hijos y la convivencia entre parientes y amigos. Al analisar las entrevistas identificamos la ausencia de medidas preventivas, falta de pesquisa sobre informaciories en lo que dice respecto del HIV, la indignación de las compañeras y la preocupación com los hijos, asi como la dificil situación entre parientes y amigos.

PALABRAS CLAVE: MUjer - SIDA - Reacción a la positividad del suero.

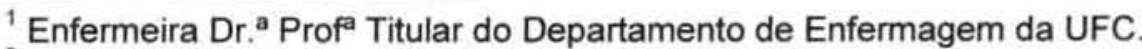

${ }^{2}$ Acad. de Enfermagem. Bolsista do Programa de Iniciação Cientifica da UFC.

${ }^{3}$ Profa $^{\text {. Assistente do Dept }}{ }^{\circ}$. de Enf. da UECE e Especialista em Saúde Pública.

R. Bras. Enferm. Brasilia, v. 51, n. 3, p. 393-402, jul./set., 1998 


\section{INTRODUÇÃO}

A contaminação pelo virus HIVIAIDS dentro do casamento é um problema que envolve fatores culturais, sociais e econômicos, situando a mulher em grupos distintos, dos quais se destacam as donas de casa, mães (com filhos) e as prostitutas que vivem nas ruas, estando, portanto, mais vulneráveis às DSTs, particularmente a AIDS. Este agrupamento leva a uma visão distorcida sobre a sexualidade da mulher, influenciando diretamente na negociação do sexo seguro.

O que se pode perceber é que, ao ter parceiro fixo, a preocupação passa a ser do outro e não sua (Loyola, 1994). Por esta razão, nenhuma medida de prevenção é adotada, levando a uma possivel contaminação, já que os parceiros muitas vezes se expőem ao risco quando traem a confiança do outro.

De acordo com o Boletim Epidemiológico do Ministério da Saúde, o número de mulheres que se contaminaram com o HIV vem aumentando, e, até agosto de 1997, a estatistica nos mostra que, para cada mulher infectada com o virus da AIDS, existem três homens.

O crescimento da AIDS entre as mulheres em todo o globo está preocupando a Organização Mundial de Saúde, que estima existir no mundo cerca de 3 milhões de mulheres infectadas ${ }^{8}$. É importante salientar que, só no Estado do Ceará, existem aproximadamente 245 mulheres com o vírus, (MINISTÉRIO DA SAÚDE, 1997). Dentre estas mulheres, estão as esterilizadas, que acreditam não precisar de outros cuidados para evitar a doença (Biancarelli, 1994).

A rápida disseminação desta grave DST chama a atenção em relação às limitaçōes de nossa compreensão do comportamento sexual humano, bem como não há, ainda, uma tradição estabelecida da pesquisa cientifica na área da sexualidade humana e suas ligações com outros aspectos da vida (Biancarelli, 1994).

Tendo em vista questionamentos sobre grupos de risco e a existência de comportamentos de risco, torna-se cada vez mais necessário que sejam estabelecidas estratégias de educação em saúde sobre o sexo seguro. Entretanto, esta negociação entre parceiros sexuais, especialmente entre as mulheres com parceria fixa, é dificil e complexa. No advento das tecnologias contraceptivas, os homens foram definitivamente alijados desse processo, enquanto as mulheres têm pouco ou nenhum controle sobre suas decisões sexuais (Czeresnia e col., 1995).

A mulher deve exigir proteção, não podendo confiar cegamente no seu parceiro sexual, pois, mesmo dentro de uma relação estável, tendo um único parceiro, os riscos não podem ser ignorados, já que a contaminaçäo de mulheres com parceria única vem aumentando, ao passo que a contaminação das prostitutas vem diminuindo (Westrupp, 1997).

Estudos recentes nos levam a preocupação com o indice de soropositividade dos testes de HIV nas mulheres que têm parceria fixa ${ }^{4}$. Revelam-nos, também, 
que o bissexualismo por parte do parceiro é uma ameaça a essas mulheres casadas, que podem encontrar no companheiro um possivel veículo do vírus da AIDS $^{4}$.

Diante da crescente população de mulheres que não têm comportamento de risco, mas que se encontramı vulneráveis, já que seu companheiro adota comportamento de risco fora de casa, a contaminação conjugal pode abranger pai, mãe e filho(s), resultando num emaranhado de questões que precisam ser discutidas, cuidadas e resolvidas.

É sabido que a AIDS não é trabalhada isoladamente, já que existe todo um conjunto, do qual podemos destacar o medo, a ignorância, a informação deficiente e o preconceito, estando a mulher, muitas vezes, em uma posição desvantajosa, vítima da situação. A relação com o parceiro fixo não é erroneamente considerada comportamento de risco, mas percebe-se que a infidelidade no casamento pode trazer consigo o risco de contrair o HIV.

Esse problema passou a ser estudado por nós a partir da decisão de pesquisar a contaminação pelo HIV, dentro do casamento, junto a mulheres infectadas pelo virus e que freqüentam o ambulatório de um hospital especializado em doenças infecto-contagiosas no Estado do Ceará.

No contexto dessa nossa intenção, percebemos a incidência de mulheres com parceiro único e que procuravam fazer o teste do HIV. Bem assim, divisamos a existência de homens casados que contrairam o virus fora do matrimônio e sentiam dificuldades de falar para a mulher. De acordo com esta experiência, foi sentida a necessidade de se investigar os riscos e as ocorrências da contaminação pelo HIV dentro do casamento, sob a óptica da companheira. Objetivamos refletir sobre a situação da mulher, que contraiu HIV do companheiro, frente à familia e ao futuro de seus filhos.

\section{METODOLOGIA}

A contaminação do(a) companheiro(a) pelo virus da AIDS é estudada através de pesquisa qualitativa, com enfoque mini-etnográfico. Esse tipo de estudo permite observar, detalhar, descrever, documentar e analisar o estilo de vida ou padrões específicos de uma cultura. Neste caso, objetivamos descrever a contaminação pelo HIV no relacionamento conjugal. O estudo abrangeu as seguintes etapas: exploração, decisão e descoberta (Ludke; André,1986).

A pesquisa teve duração de aproximadamente seis meses, tempo durante 0 qual pudemos acompanhar o aconselhamento pré e pós-teste para o HIV. A primeira fase, a exploração, teve início no dia 15 de março de 1996, quando, através de acompanhamento sistematizado, nos foi dado perceber a dinâmica do serviço e identificar o problema, com vistas ao desenvolvimento da pesquisa.

O pré e pós-teste do HIV constituem práticas desenvolvidas por uma equipe multiprofissional, composta por enfermeiras, psicólogas, assistentes sociais e um médico, que trabalham no hospital de doenças infecto-contagiosas no Estado do Ceará. Este hospital é um centro de referência para quem deseja fazer o exame 
e saber se é HIV positivo, sendo também um lugar onde os portadores podem contar com a medicação e tratamento para as doenças oportunistas, que os acometem em decorrência da imunodepressão. Esses clientes têm na equipe que os assiste a oportunidade de serem atendidos e a garantia de que o sigilo diante do resultado, seguramente será respeitado.

De acordo com o pré e pós-teste para o HIV, pudemos constatar que o número de pessoas que procuram fazer o teste do HIV é elevado, principalmente as que se encontram na faixa etária entre 20 e 30 anos, sendo mais freqüente a presença de mulheres e homens homossexuais. Já os usuários de drogas têm uma presença menos significativa, pois só aparecem se nas instituiçöes de recuperação por eles freqüentadas for exigido o teste do HIV. Por outro lado, temos a população masculina heterossexual que dificilmente procura esse tipo de atendimento.

Diante das diversas observaçöes, foi dificil tomarmos a decisão sobre a amostra que seria direcionada à pesquisa. Mas a incidência de mulheres que contraíram o HIV de seu companheiro nos chamou a atenção, levando-nos a optar por investigá-las.

Houve uma triagem das mulheres com a finalidade de que as informantes atendessem aos pré-requisitos da pesquisa. Também existiu toda uma explicação sobre os objetivos da investigação para que as informantes ficassem sabendo do que se tratava e com isso se sentissem mais à vontade em relação ao trabalho que seria desenvolvido junto a elas. A seleção da amostra foi constituida de cinco mulheres, com adesão espontânea, que se encontravam nos ambulatórios e em internações hospitalares num hospital de doenças infecto-contagiosas no Estado do Ceará.

Com a finalidade de respeitar o sigilo, bem como os principios éticos inerentes à pesquisa, as mulheres entrevistadas tiveram os seguinte nomes ficticios: Maria, Mira Moura, May e Madi.

Houve uma série de cuidados próprios a qualquer tipo de entrevista. Preliminarmente, um respeito pelas pessoas, perfeita garantia do sigilo e anonimato em relação à informante. Uso de vocabulário adequado ao nivel de instrução do informante, o que propiciou constatássemos no desenvolvimento uma grande capacidade delas de ouvir atentamente e estimular o fluxo natural de informações ${ }^{7}$.

A entrevista aplicada constou de perguntas que se direcionaram à possibilidade, não remota, de contaminação pelo HIV dentro do casamento. As falas das mulheres foram analisadas e condensadas, passando a ser relatadas as frases mais significativas para o estudo.

Para explicar a realidade e situar as várias descobertas no contexto cultural de mulheres que contrairam o HIV dos seus companheiros, analisamos os resultados da entrevista simultaneamente à observação que acompanhou todo o estudo. 


\section{RESULTADOS E COMENTÁRIOS}

\section{Convivendo com as mulheres}

Maria - Casada, 19 anos, católica, sem filhos, acreditava que nunca iria contrair o virus da AIDS. Contudo, o marido teve que fazer uma cirurgia e dentre os exames aos quais foi submetido, detectou-se o vírus da AIDS. Maria ficou chocada e esperou criar coragem para fazer o exame (mais ou menos uns 6 meses); nesse meio tempo, ela não teve relações com o marido, mas, infelizmente, ao fazer o teste, recebeu como resultado a confirmaçäo de que era uma portadora. Foi um momento muito dificil, mas teve total apoio da família.

Até hoje, ela não sabe ao certo como seu marido contraiu porém, acha ter sido de um pacto de sangue que fez com os amigos ou até mesmo de mulher. De acordo com os dados do marido e com o pouco tempo de casados, tudo indica que ele contraiu bem antes de se casar com Maria, assim afirmou.

Mira - Viúva, 37 anos, protestante, mãe de dois filhos, também achava que nunca iria contrair o HIV, pois acreditava na fidelidade do companheiro. Ele apresentou algumas complicações de saúde e o médico pediu que ele fizesse o teste do HIV e Mira ficou sabendo. No dia do resultado, ela foi com ele buscar o exame e puxou da mão da enfermeira, vendo o resultado positivo do exame. Ela se desesperou e queria matá-lo.

Depois de saber o resultado positivo do companheiro, Mira foi fazer o teste e a confirmação de que era portadora do vírus da AIDS só ocorreu no terceiro exame. Apesar dela estar com uma certa esperança, infelizmente era soropositiva, dizendo que nunca mais se curaria.

Maura - Solteira, 21 anos, sem religiäo mas acredita em Deus, não tem filhos, convivia com o namorado desde os 14 anos, que aparentemente não demonstrava ser um portador de doença alguma. Acreditava muito na conduta dele, mas esta saúde de ferro começou a desabar e ela, acompanhando sua decadência, descobriu que ele estava com AIDS. Ela nunca tinha se preocupado em usar camisinha e, quando ficou sabendo que o namorado era soropositivo, a preocupação tomou conta dela. Ao fazer o teste, deparou-se com um resultado positivo. Quando tal ocorreu, ela tinha 16 anos. Hoje ela se encontra com 21anos e ainda não desenvolveu a AIDS.

Provavelmente, ele adquiriu o virus da AIDS de condutas homossexuais, pois, depois de sua morte, Maura, ao procurar um hospital para ser acompanhada no tratamento, conheceu um doente de AIDS, que lhe contou ter tido um caso com o seu antigo parceiro.

May - Casada, 33 anos, católica, mãe de cinco filhos. Ao saber que o marido tinha contraido o virus da AIDS, May foi fazer seu teste e, logo na primeira vez, resultou positivo. Ao receber o teste, ela disse que pensou em se matar, pensou nos filhos e em inúmeras outras coisas. Sabia que seu marido era muito "farrista", usava drogas e levava uma vida muito promíscua quando saia para trabalhar, pois ele era cantor de uma banda de pagode, tendo, portanto, que viver viajando. E em uma dessas suas viagens e farras contraiu o HIV. 
Madi - Desquitada, 38 anos, católica, mãe de três filhos, vivia em concubinato com o companheiro. Passou a achar estranhas certas atitude dele, a quantidade e a constância de remédios que ele estava tomando, mas ela não desconfiou do real problema. Madi teve que fazer uns exames e, por curiosidade, fez o teste do HIV para saber se realmente alguns boatos eram verdadeiros. Ao fazer o exame, ela ficou sabendo que era uma portadora. Diante do resultado, não quis mais conviver com o companheiro $₹$ entrou em uma profunda depressão. Fez um tratamento rigoroso para se recuperar do trauma e poder cuidar de seus filhos.

\section{Descrevendo e analisando o resultado das entrevistas}

Felizmente, não encontramos dificuldades para a realização desta pesquisa, pois a aceitabilidade, por parte das mulheres, ocorreu em grau bastante satisfatório. Ao cooperarem com a pesquisa, elas transmitiram a necessidade de desabafar os seus problemas e mostrar as suas experiências, como exemplo para muitas outras mulheres que se encontram nesta mesma situação. $\dot{E}$ importante lembrar que, apesar da "diversidade" dos universos abordados, essas mulheres tinham um ponto muito forte em comum: eram fiéis aos seus companheiros, e por acreditarem na reciprocidade de seus sentimentos contraíram o HIV, e hoje vivem situações parecidas.

Quanto ao impacto diante do resultado positivo, as informantes relataram algumas de suas dificuldades vivenciadas, ao saberem que eram portadoras do HIV. Constatamos que o preconceito e a discriminação estavam presentes como barreiras muito fortes para todas, e elas teriam que enfrentar e tentar superá-las. Por outro lado, também foi possivel verificar o isolamento social, o medo da morte e alguns conflitos psicológicos. Vale ressaltar que a curiosidade das pessoas e a reação de certas familias tiveram uma influência negativa neste contexto.

As falas das mulheres que contrairam HIV do companheiro refletem a seguinte situação:

O que doeu mais foi saber que eu não podia contar com ninguém. Eu ficava imaginando que ter o HIV eu tinha uma sentença de morte, tenho uma sentença de morte. O que foi mais difícil pra mim mesmo foi o preconceito e a discriminação. Foi um choque muito forte, eu pensei em me suicidar, eu tentei suicídio ainda, tomei duas caixas de tranqüilizantes.

Todas essas falas nos mostram como é dificil "enfrentar", ou seja, diante de uma situação estressante, buscar forças para superar os obstáculos principalmente quando estes estão relacionados a uma doença sem cura, que terá repercussão na vida conjugal, profissional e familiar (Westrupp,1997).

Em relação ao comportamento do companheiro, as falas das entrevistadas variavam desde o marido "farrista" até o "comportado".

Era um jovem por quem qualquer mulher colocaria a mão no fogo. Eu dizia: esse homem é muito saudável, esse homem não usa drogas, não é promíscuo. Só foi mulher e cachaça droga, tudo. Ah! desconfiava, sempre desconfiei que 
ele tinha é, corria esse risco, mas eu não acreditava. Eu confiava muito nele, a gente era muito louco um pelo outro, mas hoje eu vejo que ele tinha uma vida de risco, mas eu achava que não tinha.

Aparentemente os comportamentos eram diferentes, entretanto, é sabido que ao homem é dado o direito de fazer sexo com outras parceiras, além de sua companheira, só que, culturalmente, não é aceito pela sociedade o fato de o homem ter relações com outros homens (Westrupp, 1997).

Por acreditarem no companheiro, achavam que nunca poderiam contrair o vírus da AIDS, ou, se desconfiavam do comportamento dele, não se preocupavam com a sua proteção.

Foi percebido que as formas de prevenção antes da contaminação estavam voltadas para a contracepção e não para as DSTs/AIDS. Segundo as informantes, elas não achavam que poderiam contrair o HIV, já que tinham parceiro único e a maioria acreditava que o companheiro pudesse ser fiel como eram elas. Relataram também que elas nunca sugeriram o uso de contraceptivos e, em um dos casos, a companheira afirma que o seu parceiro sabia que era portador do vírus e mesmo assim não sugeriu o uso da "camisinha", pois dizia que não gostava ou que não era necessário.

A prevenção contra a AIDS não existia, o que levava algumas vezes ao uso do condon era a preocupação em não engravidar, como podemos ver:

A minha preocupação era não engravidar. Ele dizia: eu não vou usar "camisinha", num sei que, eu lá gosto de camisinha...mas ele dizia que me amava, ele me tratava de uma maneira que eu achava que ele não tinha... eu acreditava no amor dele e não tinha coragem de fazer isso comigo... a mulher sempre pensa "tô protegida porque sou direita".

A reação frente ao HIV positivo do companheiro constou de comportamentos que divergiram entre apoiar o companheiro ou abandoná-lo. As mulheres que ajudaram o marido afirmam sentir pena deles e acabam por se acomodar com a situação.

Tive muita pena dele, afinal é pai dos meus filhos. Ele estava tão doente que não tive coragem de abandonar

Por outro lado, as que abandonaram o companheiro disseram que a dor e o sentimento de traição não permitiram que suportassem o convivio com 0 responsável por toda esta situação na qual elas estavam vivendo e morrendo.

Me senti traida, era assim, porque eu pensei se ele estava com AIDS, ele não pegou de mim, porque ele era o primeiro homem de minha vida e eu não nasci com AIDS. Foi desespero total, eu tive vontade de matá-lo, e eu teria coragem se eu tivesse tido oportunidade.

Observamos que a fidelidade na sociedade foi apreendida apenas pelas mulheres que carregam em si a honra masculina, já os homens não assimilaram o sentido da palavra e nem põem em prática esta "fidelidade", tendo em vista que para eles não existem cobranças (Westrupp, 1997). 
A opiniäo sobre a contaminação pelo HIV antes de contraí-lo era de que a AIDS estaria restrita a grupos de risco e nunca seria uma doença delas. Por outro lado, a visão distorcida do que é "sexo seguro" reflete a falta de conhecimento destas mulheres sobre a AIDS e um potencial favorável à contaminação pelo virus.

Eu achava que existir, existia, mas eu achava que não ia acontecer comigo. Minha opinião era que os grupos de risco era só homossexual, era a prostituta, eram as pessoas que viviam fazendo sexo sem segurança.

As prostitutas e os homossexuais foram tidos como os grupos de risco da AIDS, deixando desta forma as pessoas sem se darem conta de que a epidemia está a bater na porta de cada uma de nossas casas (Westrupp, 1997).

Depois de contrair o HIV, a opinião destas mulheres mudou bastante, pois, ao vivenciarem a realidade da contaminação pelo virus da AIDS, passaram a acreditar que não existe distinção quanto a sexo, cor ou qualquer grupo especifico.

Eu vejo hoje como uma doença que não escolhe mais sexo, preferência sexual, ela não escolhe cor/religião, ela não escolhe classe social, ela não escolhe conduta sexual. Dentro do casamento a mulher não está segura. Hoje para mim não existe grupo de risco, existe sexo com risco.

A incidência de casos de AIDS vem a cada dia nos mostrando que ela não está restrita a determinados grupos, mas sim a todos, homens e mulheres que não estão se prevenindo (Westrupp, 1997).

Algumas informantes se sentiram isoladas, sem poder contar com ajuda de ninguém. Depois, algumas passaram a receber medicação do hospital, anteriormente citado, e apoio de psicólogas e enfermeiras para superar crises depressivas e confusões de sentimentos.

Eu tenho mais apoio aqui no hospital do que lá em casa, porque no hospital eles me entendem.

O apoio de parentes e amigos desejado por todas elas nem sempre aconteceu, pois, em algumas situaçōes, a familia, dotada de um preconceito exacerbado, não se sensibiliza com o estado da portadora. Preocupando-se apenas com a opiniäo da sociedade, chegam a colocar a filha na rua, e acham que com isso o problema vai estar resolvido.

Para a minha familia eu sou um motivo de vergonha: não tenho apoio de ninguém.

Por outro lado, a maioria refere ter encontrado como suporte o apoio de sua familia.

Eu sabia que ia poder contar com a minha familia. Só a familia, amigos nenhum, eu já tinha pouco e depois disso é que se afastaram mesmo.

Hay (1990) comenta que o amor e o apoio que se oferece para os doentes de AIDS serão de mais utilidade que qualquer medicamento, principalmente quando esse amor e apoio vem de sua familia. 
Quanto ao futuro dos filhos, a preocupação em querer viver para poder deixar os filhos pelo menos encaminhados na vida não podia deixar de existir, nas que são mães.

Eu sinto um outro lado de viver por causa de meus filhos.

Por outro lado, elas sabem que o estigma da AIDS irá perseguir a vida de seus filhos e vêem como um futuro dificil o de um filho de portador.

Eu vejo como um futuro dificil, porque sempre carrega o estigma: ah! tua mãe morreu de AIDS, não foi? tua mãe era aidética!. Me preocupo como eles väo ficar.

Muitas crianças com AIDS estão sendo encontradas abandonadas nos hospitais, nos asilos, ou utilizadas para experimentação e investigação (Hay, 1990), por outro lado, observamos que o número de crianças órfãs vem aumentando, tendo como causa a morte do pai e/ou da mãe com AIDS.

\section{CONCLUSÃO}

Os depoimentos das mulheres refletem a dificil situação de portadora do HIV: o isolamento social e todo o contexto bio-psico-social em que elas se encontram e que são obrigadas a enfrentar.

Observamos que a aceitação do companheiro existiu na maioria dos casos, mostrando com isso o valor que a cultura exerce sobre as decisōes destas mulheres, que carregam em si a submissão imposta pela sociedade machista.

Por outro lado, a familia nem sempre deu apoio a estas mulheres, seja pela ignorância ou medo da sociedade. Não suportando ter um de seus componentes como portador do virus da AIDS, expulsam-no de casa, como ocorreu com uma das mulheres entrevistadas.

O preconceito e a discriminação passam a ter um peso significativo na vida destas mulheres, que chegam a temer a repercussão destes preconceitos no futuro de seus filhos.

Tendo em vista a força que os meios de comunicação exercem na população, eles precisam atuar de forma mais persistente, já que, apesar das campanhas preventivas, encontramos casos como o destas mulheres, mostrando, com isso, deficiências na informação.

\section{REFERÊNCIAS BIBLIOGRÁFICAS}

1. BIANCARELLE, Aurélio. AIDS cresce entre mulheres no mundo. Folha de São Paulo. 13 jan. 1994.

2. CEARÁ, Secretária de Saúde do Estado. Boletim Epidemiológico do estado do Ceará. Fortaleza, ANO IX. Nº1. fev. 1996. 
3. CZERESNIA, Dina et al. AIDS, pesquisa social e educação. HUCITECABRASCO.1995.

4. ESTÉBANEZ, P., NÁJERA, R. El Sida y la mujer (I). España. Editorial. Vol.2. Núm.1. Enero. 1991.

5. HAY, Louise L. EI Sida como abordarlo de forma positiva. Espanha: Urano. 1990. 285p.

6. LOYOLA, Maria Andréia (org). ; GIAMI, Alair et al. AIDS e sexualidade. Rio de Janeiro: Relumé-Dumara: UERJ,1994. 246p.

7. LÜDKE, Menga, ANDRÉ, Marli E. D. Pesquisa em educação: abordagens qualitativa. São Paulo: EPU. 1986. p.99.

8. BRASIL, Ministério da Saúde. Boletim Epidemiológico: AIDS, Brasilia,. Ano X, N 3 - Semana Epidemiológica 23-35, jun-ago, 1997.

9. UIP, David. Mulher Apaixonada corre maior risco, afirma médico. Folha de São Paulo. 11 jul. 1994. p.3-5

10. WESTRUPP, Maria Helena B. Práticas sexuais de mulheres de parceiros infectados pelo HIV: Contribuiçōes acerca da cadeia epidemiológica da transmissão do HIV/AIDS. Dissertação (Doutorado) - Universidade Federal de Santa Catarina. Florianópolis, SC. $1997.174 \mathrm{p}$. 